\title{
Pengaruh Selebriti Endorser Instagram Terhadap Minat Beli Followers
}

\author{
Sabrina Dimeila, Farid \\ sabrindml@gmail.com farid@fikom.untar.ac.id
}

Fakultas Ilmu Komunikasi, Universitas Tarumanagara.

\begin{abstract}
Now days many Instagram account owners become celebrity endorsers of a product. The purpose of this research is to be discussed about Celebrity Endorser Instagram @awkarin Against the Followers' Interest in Buying. The researcher used four theories namely Social Media, Instagram, Celebrity Endorser and Buying Interest. The role of celebrity endosers is to advertise various products to attract attention or interest in buying followers of the account. Celebrity Endorsers have four indicators namely: visibility, credibility, attractiveness, strength. While the variable Buy Interest has four indicators: attention, interest, desire, action. The researcher used a quantitative method with a contribution of 4.3 million followers to the Instagram account @awkarin with a sample of 100 respondents. Based on the results of testing the coefficient $(R)$, celebrity support for buying interest is included in the medium category with a number of 0.457. In addition, looking at the results of hypothesis testing between the Celebrity Endorser variable $(X)$ and the Purchase Interest variable $(Y)$ shows a balanced result Celebrity Endorser $(X)$ has no influence on followers. But from the Interest variable, Buy has an interest in followers' interests. In addition, from the t-test, it was shown that followers from Instagram did not see the role of @awkarin as a celebrity endorser, but they looked more at endorsed products so that they were involved in buying followers' interests .
\end{abstract}

Keyword: Social Media, Instagram, Celebrity Endorser.

\begin{abstract}
Abstrak
Saat ini banyak pemilik akun instagram menjadi selebriti endorser dari sebuah produk. Tujuan penelitiaan ini untuk mengetahui Pengaruh Selebriti Endorser Instagram @awkarin Terhadap Minat Beli Followers. Peneliti menggunakan empat teori yaitu Sosial Media, Instagram, Selebriti Endorser dan Minat Beli. Peran selebriti endoser yaitu mengiklankan berbagai produk untuk menarik perhatian atau minat beli para pengikut akun tersebut. Selebriti Endorser memiliki empat indikator yaitu : visibility, credibility, attraction, power. Sedangkan Variabel Minat Beli memiliki empat indikator :attention, interest, desire, action. Peneliti menggunakan metode kuantitatif dengan populasi followers akun instagram @ awkarin sebanyak 4,3 juta pengguna dengan sampel 100 responden. Jawaban dari hasil uji koefisien korelasi terpengaruh selebriti endorser kepada minat beli termasuk sedang dengan jawaban 0.457. Selain itu melihat hasil jawban dari uji thipotesis diantara Selebriti Endorser (X) dan variable Minat Beli (Y) dapat hasil berimbang seperti Selebriti Endorser (X) tidak memiliki pengaruh terhadap followers. Tapi dari variabel Minat Beli ada pengaruh terhadap minat followers. Selain itu dari uji t menunjukkan bahwa followers dari Instagram kurang melihat peran@awkarin sebagai selebriti endorser tetapi mereka lebih melihat terhadap produk yang di endorse sehingga menimbulkan pengaruh terhadap minat beli followers
\end{abstract}

Kata Kunci: Sosial Media, Selebriti Endorser, Instagram, Minat Beli 


\section{Pendahuluan}

Seiring berjalannya waktu, penggunaan media cetak sudah semakin berkurang. Saat ini sebagian masyarakat lebih memilih membaca sebuah informasi atau ingin membeli sesuatu melalui media massa. Media massa yang sedang banyak diminati yaitu media online. Media sosial kini sudah sering digunakan oleh berbagai kalangan dari kalangan muda sampe kalangan dewasa sudah menggunakan media sosial sebagai sumber informasi. Perkembangan dari teknologi yang maju, terdapat adanya berbagai macam media ikut berkembang contohnya adalah sosial media.

Perkembangan teknologi yang sedang berkembang seperti Instagram. media ini yang berisikan tentang foto-foto serta video yang menarik perhatian para pemilik akun Instagram.

Sebagai salah satu contohnya adalah Instagram @Awkarin yang memanfaatkan media sosial Instagram dengan melakukan Endorser. Endorser adalah produk yang diiklankan oleh pemilik akun Instagram tersebut. Awkarin merupakan salah satu pengguna Instagram yang banyak dikenal oleh pengguna Instagram sehingga dia dapat disebut sebagai selebriti endorser.

Akun Instagram @awkarin memiliki jumlah followers 4,3 juta per tanggal 18 Februari 2019. Awkarin sering membuat para followers tertarik dengan postingan endorse yang diupload olehnya. Salah satu postingan endorser yang menarik dibuat oleh Awkarin adalah video penyampaian mengenai produk tersebut. Karena didalam video tersebut dia membuat menarik perhatian dalam segi mengedit video dan cara penyampaian dalam video tersebut menarik.

Dampak dari postingan video yang dia buat, membuat para followers ingin membeli dari produk tersebut. Para followers awkarin menjadi percaya dan tertarik terhadap setiap postingan endorser yang diiklankan olehnya.

Penulis ingin pembuktian dengan menggunakan penelitian hal ini, endorser instagram @awkarin dapat memberi pengaruh terhadap minat beli followers. Hasil tersebut sesuai dengan pembahasan diatas penulis menggunakan penelitian dengan judul:

"Pengaruh Selebriti Endorser Instagram @awkarin terhadap Minat Beli Followers".

Penulis memakai teori, seperti berikut:

a. Teori Media Sosial

Teori tersebut digunakan pemikiran dari Van Dijk, pengertian dari teori yang berarti media yang berfokus pada pengguna yang berfasilitasi untuk melakukan aktivitas kerjasama. Karena itu dapat berguna sebagai media yang memperkuatkan suatu hubungan dari pengguna sekaligus sebagai sebuah pengikat komunikasi.

\section{b.Instagram}

Instagram yaitu platform yang sedang sangat diminati oleh berbagai kalangan. Banyak berminat karena memiliki fitur-fitur yang menarik yaitu pengikut, mengunggah foto dan video, kolom komentar, filters, mengirim link.

\section{c. Selebriti Endorser}

Hasil dari pemikiran Shimp bahwa pengertian dari endorse adalah sebagai membantu iklan atau yang dikenal juga sebagai bintang iklan untuk mendukung suatu produk.Sedangkan arti dari selebriti merupakan seorang tokoh, atau penghibur yang 
dikenal berdasarkan prestasinya di dalam bidang-bidang yang berbeda dari produk yang đidukungnya (Shimp, 2003).

Menurut Royan (2004), indikator selebriti endorser yaitu ada empat :

1. Visibility, yaitu untuk lihat seberapa tinggi popularitas dari selebriti.

2. Credibility, yaitu berkaitan dari pengetahuan mengenai barang yang dikenal oleh artis.

3. Attraction, yaitu untuk melihat seberapa besar kehebatan sang bintang.

4. Power, yaitu melihat kehabatan dari seorang artis dalam daya tarik a. Minat Beli pengikut untuk beli barang yang telah diendorse olehnya.

Assael (2001) membuat pengertian dari minat beli yaitu melihat kecenderungan seorang pembeli untuk beli barang atau sebuah keputusan yang dihubungkan kepada pembelian yang dapat dihitung dengan kemungkinan seorang konsumen untuk menjalankan pembelian.

Arti dari minat beli suatu tindakan yang merupakan hasil pertimbangan dari seorang calon pembeli saat membeli suatu produk. Minat Beli juga terjadi saat calon pembeli mendapatkan daya tarik terhadap suatu produk yang ingin dimiliki.

Suwandari mengatakan (dalam Rizky dan Yasin, 2014), minat beli memiliki empat indicator yaitu:

a. Perhatian (Attention)

Perhatian mengacu pada menarik perhatian pembelli terhadap barang yang dijual oleh penjual.

b. Ketertarikan

Pengertian dari ketertarikan yaitu melibatkan ketertarikan seorang calon pembeli bagaimana konsumen menilai suatu produk yang dijual oleh produsen.

c. Keinginan (Desire)

Keinginan merupakan suatu reaksi seorang calon konsumen untuk ingin memiliki produk yang dijual oleh produsen.

d. Tindakan (Action)

Tindakan merupakan suatu reaksi calon konsumen dengan adanya pembelian terhadap barang yang dijual.

\section{Metode Penelitian}

Penulis menulis penelitian ini dengan digunakan metode penelitian kuantitatif. Menurut Sugiyono (2012:5) dijelaskan metode penelitian dapat diartikan menggunakan cara ilmiah untuk data yang valid dengan tujuan dapat ditemukan, dikembangkan, dan dibuktikan, suatu pengetahuan tertentu sehingga pada gilirannya dapat digunakan untuk memahami, memecahkan dan mengantisispasi masalah

Dari penjelasan mengenai penelitian kuantitatif menurut para ahli seperti diatas, dapat disimpulkan bahwa pengertian dari penulisan kuantitatif yang digunakan angka saat melakukan proses penghitungan. Proses tersebut supaya mendapatkan data yang valid dan sudah memecahkan suatu masalah. 


\section{Hasil Temuan dan Diskusi}

Table 1

Koefisien Korelasi (R) Variabel Selebriti Endorser (X)

\begin{tabular}{|c|c|c|}
\hline & $\mathbf{R}$ & $\mathbf{R}^{2}$ \\
\hline Selebriti Endorser & 0.902 & 0.813 \\
\hline \multirow{2}{*}{\multicolumn{3}{|c|}{$\begin{array}{l}\text { Sumber : jawaban yang diperoleh dengan SPSS } \\
\text { Table } 2 \\
\text { of Significant ( Uji t ) Variabel Selebriti Endorser ( } \mathbf{X} \text { ) }\end{array}$}} \\
\hline & & lat Beli \\
\hline-0.786 & $\mathbf{T}$ & -3.810 \\
\hline 1.120 & Sig & 0.000 \\
\hline
\end{tabular}

a. Berdasarkan tabel 1, disimpulkan nilai dari koefisien korelasi ( $\mathrm{R}$ ) untuk Selebriti Endorser (X) yaitu 0.902. Berarti adanya hubungan antara X dan Y menyatakan sangat tinggi yaitu ada dalam interval $0.8-1.00$.

b. Tabel no 2 , disimpulkan hasil dari uji t untuk selebriti endorser jawaban mengenai nilai t yaitu -3.810 dan sig sebesar 0.000. Berarti Sig. hitung < 0.05 yaitu $0.000<0.05$. Hasil tersebut ditujukan Ha ditolak, bahwa variabel (X) secara personal tidak adanya pengaruh terhadap followers.

hasil uji t antara Selebriti Endorser (X) dan variable Minat Beli (Y) hasilnya yang berimbang, Selebriti Endorser (X) dari Instagram @awkarin tidak ada pengaruh terhadap Followers, tetapi terdapat pengaruh terhadap Minat Beli followers.

Dalam penelitian ini, selama responden meihat posting produk endorse awkarin banyak yang informasi endorse yang disampaikan oleh Awkarin mempengaruhi keputusan pembelian, dari berdasarkan ada yang dilihat tanpa disadari minat beli followers akan pengaruh, dari pertanyaan yang telah disebar, 28 dari 100 orang menjawab sangat menyetujui dengan pertanyaan menginginkan produk yang diendorse oleh Awkarin karena produk tersebut cukup menarik. 32dari 100 responen sangat setuju bahwa bila menemukan barang yang diinginkan di endorse oleh Awkarin, responden akan membelinya berdasarkan jawaban uji koefisien korelasi (R) sendiri, pengaruh selebriti endorser terhadap minat beli sebagai kategori sedang dengan angka 0.457 .

Selanjutnya, melihat pada koefisien determinasi ( $\mathrm{R}^{2}$ ), diketahui bahwa pengaruh Selebriti endorser (X) kepada Minat beli ( $\mathrm{Y}$ ) yaitu 81,3\%, yang berarti 18,7\% yang lain yaitu merupakan faktor lain dapat berpengaruh namun tidak dibutuhkan dalam hasil diteliti ini. Kesimpulan selebiritis endorser awkarin berpengaruh terhadap followers, isi penelitian ini, yaitu menggunakan unsur Selebriti endorser pengaruh $81,3 \%$.

Sesuai pembahasan di atas, dapat jawaban bahwa instagram awkarin sebagai selebriti endorser dari media sosial memiliki pengaruh terhadap followers ada minat beli seperti orang membeli produk awkarin jika produk tersebut dibutuhkan.

\section{Simpulan}

adanya jawaban uji dari menganalisis yang dijelaskan pada bab empat, dapat disimpulkan: 
1. Berdasarkan kesimpulan diperoleh hasil dari koefisien korelasi untuk Selebriti Endorser (X) merupakan 0.902. yang berarti adanya hubungan dari $\mathrm{X}$ dan $\mathrm{Y}$ dinyatakan sangat tinggi karena ada didalam interval $0.8-1.00$.

2. Disimpulkan koefisien determinasi memakai jawban $\mathrm{R}$ Square yaitu berjumlah 0.813 artinya terdapat mempunyai kehebatan selebriti endorser (X) dalam dependen minat beli (Y) adalah sebesar 81,3\%, sedangkan 18,7\% faktor lain yang tidak ditulis dalam model regresi penelitian ini.

Sesuai tabel diatas, mendapatkan jawaban dari uji t selebriti endorser dilihat nilai $\mathrm{t}$

-3.810 dan signifikan sebesar 0.000. Dengan begitu menunjukan Ha ditolak, bahwa variabel (X) secara personal tidak memiliki pengaruh terhadap followers, tapi berpengaruh pada Minat Beli Followers(Y).

Sesuai yang ditemukan semakin tinggi visibility,credibility,attraction,power terhadap selebriti endorser awkarin maka tambah tinggi pula pengaruh pada minat beli followers mengenai produk endorse tersebut. contoh yang membuktikan dari pertanyaan yang diisi oleh responden yaitu, pertanyaan yang ke- 5 dalam kuesioner. 35 dari seratus orang berpendapat sangat menyetujui dengan pertanyaan mengenai Awkarin memiliki kemampuan yang cukup untuk mengiklankan suatu produk yang di endorse.

\section{Saran}

Berikut merupakan saran yang bisa peneliti bagi untuk para peneliti berikutnya:

1. Akademis

a. Lebih mempelajari lagi variabel yang akan diteliti, seperti peneliti yang harus mendalami variabel selebriti endorser dan minat belu yang memeliki pengertian dan konsep, asumsi yang sangat luas.

b. Lebih dikembangkan lagi dengan menggunakan metode kualitatif, seperti meneliti dampak dari endorse awkarin.

2. Praktis

a. Diharapkan media sosial instagram dapat terus berkembang dan dapat berguna untuk menjadi media alternatif lainnya untuk menyampaikan pesan kepada masyarakat luas.

b. Peneliti berharap masyarakat dapat lebih bisa melakuan keputusan pembelian saat ingin membeli produk endorse dengan baik dan sesuai kebutuhan.

\section{Ucapan Terima Kasih}

Ucapkan rasa syukur saya pada Tuhan, sudah memberi berkat kepada saya dapat menyelesaikan laporan penelitian dalam mata kuliah skripsi.

Skripsi adalah mata kuliah khusus yang wajib diambil oleh mahasiswa/i Fakultas Ilmu Komunikasi Universitas Tarumanagara bidang peminatan jurnalistik untuk pemenuhan syarat-syarat guna mencapai gelar sarjana studi program strata 1 (satu) Ilmu Komunikasi.

Saya sadar jika penulisan skripsi ini tidak dapat terwujud tanpa bantuan dan didukung dari berbagai pihak. Sebab itu pada saat ini saya ingin memberi ucapan terima kasih kepada yang terhormat : 
1. Ibu Dr. Riris Loisa, M.Si. Dekan dan Pembantu Dekan I Bidang Akademik dan Kemahasiswaan Fakultas Ilmu Komunikasi Universitas Tarumanagara

2. Bapak Yugih Setyanto S.sos.M.si.Wakil Dekan Fakultas Ilmu Komunikasi Universitas Tarumanagara.

3. Ibu Sinta Paramita S.I.P.,M.A. Kaprodi Fakultas Ilmu Komunikasi Universitas Tarumanagara.

4. Bapak Farid, S.S., M.Si.. selaku dosen pembimbing skripsi yang senantiasa membantu dan memberi arahan kepada penulis dan meluangkan waktunya untuk dapat memberi arahan kepada penulis. Tanpa beliau, penulis tidak mampu menyelesaikan skripsi ini tepat waktu.

5. Semua Dosen Fakultas Ilmu Komunikasi Universitas Tarumanagara yang telah memberikan berbagai ilmu dan pengetahuan yang bermanfaat bagi saya.

6. Papa,Mama,Kakak Yekhonya dan Adwin yang selalu memberi semangat, motivasi, serta selalu mendoakan saya untuk menyelesaikan tugas-tugas baik dari perkuliahan.

7. Putri Oktavia Haliem, Damba Dwismara, Kevin Arief yang sudah membantu penulis disaat mengalami kebingungan saat mengerjakan laporan skripsi

8. Serta kepada Astrid, Claresta, Renata, Indyra, Cassia, Andrea, Kent, Samuel selalu memberikan dukungan yang sangat baik seperti memberi nasihat kepada penulis.

9. Teman-teman satu fakultas yaitu Tivanny, Vereen, Helen, Michelle Cen, Stevini, Nelly, Nevelyn, Evelyn, Sonya, Axel yang sudah membantu saya dan memberikan dukungan dalam proses penyusunan proposal skripsi hingga selesai.

10. Serta teman-teman dari SMP yaitu Galuh, Indri, Saras, Andita yang selalu memberikan semangat kepada penulis hingga skripsi ini selesai.

11. Kepada Natasya Misel, Essy Pratiwy yang memberikan dukungan kepada penulis saat mengerjakan laporan skripsi

12. Para pengisi kuesioner atau dari Followers @Awkarin yang sudah meluangkan waktu untuk menjawab kuisioner.

13. Semua pihak yang tidak dapat disebutkan satu persatu telah membantu penyelesaian laporan.

Bantuan dan dukungan yang telah diberi untuk saya dapat berguna dengan sebaikmungkin oleh saya. saya sadar masih ada kekurangan dalam penyusunan laporan isi skripsi ini baik dalam teknik penyajian materi maupun yang telah dibahas. Oleh karena itu segala saran maupun kritikan yang bersifat membangun sangat diharapkan.

\section{Daftar Pustaka}

Abdullah, Thamrin (2003), Manajemen Produksi dan Industri Kecil. Jakarta: Pusat Penerbitan Universitas Terbuka

Assael, Henry. (2001). Consumer Behavior. Edisi keenam. New York: Thomson Learning.

Ashari, Purbayu Budi Santoso. (2005). Analisis Statistik dengan Microsoft Exel dan SPSS. Yogyakarta: Andi

Cetakan Keempat. Semarang: Badan Penerbit Universitas Diponegoro.

Ghozali, Imam. (2006). Aplikasi Analisis Multivariate Dengan Program SPSS. 
Ghozali, Imam. (2016). Aplikasi Analisis Multivariete Dengan Program. IBM SPSS 23 (Edisi 8). Cetakan ke VIII. Semarang : Badan Penerbit.

Husein, Umar. 2008. Metode Penelitian Untuk Skripsi dan Tesis Bisnis. Jakarta. PT Rajagrafindo Persada

Kriyantono, Rachmat. (2010). Teknik praktis riset komunikasi: disertai contoh praktis riset media, public relation, advertising, komunikasi organisaso,

komunikasi pemasaran. Jakarta: Kencana

Meikle, G., \& Young. S, 2012. Media Convergnce: Networked Digital Media in Eveyday life, Basingstoke: Palgrave Macmillan.

Nisfiannoor, Muhammad. (2013). Pendekatan Statistika Modern: Aplikasi dengan

Software SPSS dan E-Views. Jakarta: Penerbit Universitas Trisakti

Rangkuti, Freddu (2002). Measuring Customer Satification Teknik Mengukur dan strategi meningkatka kepuasan pelanggan dan analisis kasus PLN-JP, PT Gramedia Pustaka Utama, Jakarta

Rizky, M.F. \& Yasin, H. (2014), Pengaruh Promosi dan Harga Terhadap Minat Beli Perumahan Obama PT. Nailah Adi Kurnia Sei Mencirim Medan. Jurnal Manajemen \& Binsis, Vol. 14(2), hal. 135-143.

Royan Frans M. 2004. Sales Force (Meningkatkan Penjualan Dengan Rancangan Bangun Sales Force Effective)

Shimp,Terence (2003). Periklanan Promosi \& Aspek Tambahan Komunikasi Pemasaran.Terpadu, Jilid I ( edisi 5), Jakarta: Erlangga

Sumarwan, Ujang. 2004. Perilaku Konsumen, Teori dan Penerapannya dalam Pemasaran. Bogor: Ghalia Indonesia

Siregar, Syofian. (2015). Metode Penelitian Kuantitatif Dilengkapi Dengan

Perbandingan Perhitungan Manual \& SPSS. Jakarta: Kencana

Sugiyono, 2011. Metode Penelitian Kuantitaif Kualitatif dan $R \&$ B, Bandung:

Alfabeta

Siregar, Syofian. (2015). Statistika Terapan untuk Perguruan Tinggi. Jakarta: PT

Kharisma Putra Utama

Umar, Husein. 2004. Riset Sumber Daya Manusia Dalam Organisasi. Jakarta : Gramedia Pustaka Utama

Van Dijck, J. 2013. The Culture of Connectivity: A Critical History of Social Media, Oxford, UK: Oxford University Press

Warsito, Hermawan. 1992. Pengantar Metodologi Penelitian. Jakarta: Gramedia Pustaka Utama

Tahun 2015, Luh Dwi Mariyanti dan Gede Bayu Rahanatha Pengaruh Celebrity Endorser Dan Pesan Iklan Di Televisi Terhadap Keputusan Pembelian Pada Es Krim Walls Magnum Belgium Chocolate Vol 4 No 10

Tahun 2017, Paula Halim Pengaruh Selebriti Endorser Ayu TingTing Melalui Instagram Terhadap Minat Beli Konsumen ( Studi Kasus Pada Mahasiswi Fakultas Ilmu Komunikasi Univeristas Tarumanagara Satu Tahun 2016)

Tahun 2018, Putri Oktavia Haliem Pengaruh Terpaaan Media Line Webtoon "Wonderwall" Terhadap Opini Pembaca Mengenai Isu Kesehatan Mental

Tahun 2017, Silvia Caroline Pengaruh Celebrity Endorser Prilly Latuconsina Dan Penggunaan Televisi Sebagai Media Iklan Terhadap Keputusan Pembelian Slai Olai Versi Cocok Banget

http://eprints.ums.ac.id/50937/3/BAB\%20I.pdf

https://www.kajianpustaka.com/2018/12/pengertian-aspek-bentuk-dan-peranendorser.html 
http://eprints.mercubuana-yogya.ac.id/245/2/BAB\%20II.pdf

$\mathrm{http} / / /$ dosensosiologi.com/pengertian-penelitian-kuantitatif-ciri-dan-jenisnyalengkap/

http://eprints.dinus.ac.id/8895/1/jurnal_14036.pdf

https://media.neliti.com/media/publications/84414-ID-pengaruh-celebrity-endorserterhadap-min.pdf

https://www.instagram.com/awkarin/ 